\title{
Scaffolds Based on Silk Fibroin for Osteochondral Tissue Engineering
}

\section{ISSN: 2576-8840}

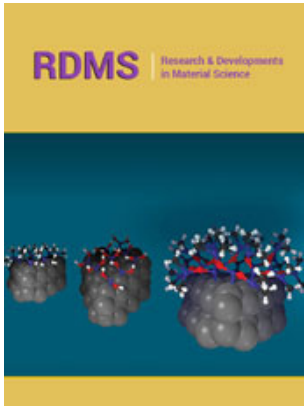

*Corresponding author: Lizeth FuentesMera, Departamento de Bioquímica y Medicina Molecular; Facultad de Medicina, Universidad Autónoma de Nuevo León, Mexico

Submission: 椬 March 27, 2019

Published: April 09, 2019

Volume 10 - Issue 3

How to cite this article: Nidia M-S, Alberto C-M, Lizeth F-M. Scaffolds Based on Silk Fibroin for Osteochondral Tissue Engineering. Res Dev Material Sci. 10(3). RDMS.000740.2019.

DOI: 10.31031/RDMS.2019.10.000740

Copyright@ Lizeth Fuentes-Mera, This article is distributed under the terms of the Creative Commons Attribution 4.0 International License, which permits unrestricted use and redistribution provided that the original author and source are credited.

\author{
Nidia Moncada-Saucedo ${ }^{1,2}$, Alberto Camacho-Morales ${ }^{1,3}$, Lizeth Fuentes- \\ Mera $^{1,2 *}$
}

${ }^{1}$ Departamento de Bioquímica y Medicina Molecular, Universidad Autónoma de Nuevo León (UANL), México

${ }^{2}$ Unidad de Terapias Experimentales, Universidad Autónoma de Nuevo León (UANL), México

${ }^{3}$ Unidad de Neurociencias, Universidad Autónoma de Nuevo León (UANL), México

\begin{abstract}
Silk fibroin protein from the silkworm Bombyx mori (B. mori) is a natural biopolymer that has extensive structural capabilities for chemical and mechanical modifications for applications in the biomedical field. The SF is versatile in its processing since it can be manufactured into different forms such as gels, films, foams, membranes, scaffolds, and nanofibers; making it an attractive material in a variety of applications that require mechanically superior, biocompatible, and biodegradable biomaterials. In this review, we present an overview of the main chemical and structural features that make silk fibroin a potential biomaterial for its wide application in tissue engineering. We discuss and summarize about different structural designs and methods for the assembly of fibroin-based 3D scaffolds emphasizing the biomedical applications of this biomaterial. Finally, we highlight the most current works in which 3D scaffolds of fibroin are used for cartilage and osteochondral tissue regeneration.
\end{abstract}

Keywords: Cartilage tissue engineering; Osteochondral tissue; Regenerative medicine; Scaffold; Silk fibroin

\section{Introduction}

Silks are polypeptides produced by members of the class Arachnida and several silkworms of the order Lepidoptera [1] that have been used in the textile industry [2], as sutures [3], in cosmetics [4], in enzymatic immobilization [5], to cover lesions [6], as a substrate for cellular growth [7,8], in systems of drug delivery [9-11], as scaffolds for tissue engineering (TE) [12], and in various advanced biomedical applications using transgenic silkworms [13,14]. Finally, silks have been considered for their application as biodegradable adhesives and sealants [15]. The use of silk as a TE biomaterial has been investigated, showing a high biocompatibility, as well as the ability to support cell growth and differentiation, in challenges as demanding as the regeneration of injured articular cartilage. The present review addresses the discoveries in the use of scaffolding systems based on silk fibroin (SF), emphasizing its application for chondral and osteochondral TE.

\section{Physical and chemical features of silk fibroin as a biomaterial}

SFs from the cocoons of the silkworm B. mori are the most-used and most-studied SFs in TE; South Korea is home to over 300 varieties of this species [16]. Silkworm cocoons primarily consist of 2 bio-macromolecules: fibroin (fibrous protein) and sericin (globular protein). The silk of $B$. mori is synthesized in a group of specialized salivary glands, and fibroin (comprising $60-80 \%$ of the silk) is synthesized exclusively in the posterior region of the gland. The fibroin fibres are covered with sericin (15-35\%), which is synthesized in the walls of the medial regions of the gland. Between 1 and $5 \%$ of the silk consists of non-sericin components, such as pigments, wax, sugars, and other impurities (Figure 1), [1,17,18].

Most lepidopterans produce fibroin that consists of 3 protein components arranged as a single element of silk: heavy-chain $(\sim 391 \mathrm{kDa})$ and light-chain fibroins $(\sim 25 \mathrm{kDa})$, which are linked by a disulphide bridge, and P25 ( $\sim 25 \mathrm{kDa})$, also known as fibrohexamerin (Fhx), These components are present at a 6:6:1 ratio, respectively [19-21]. 


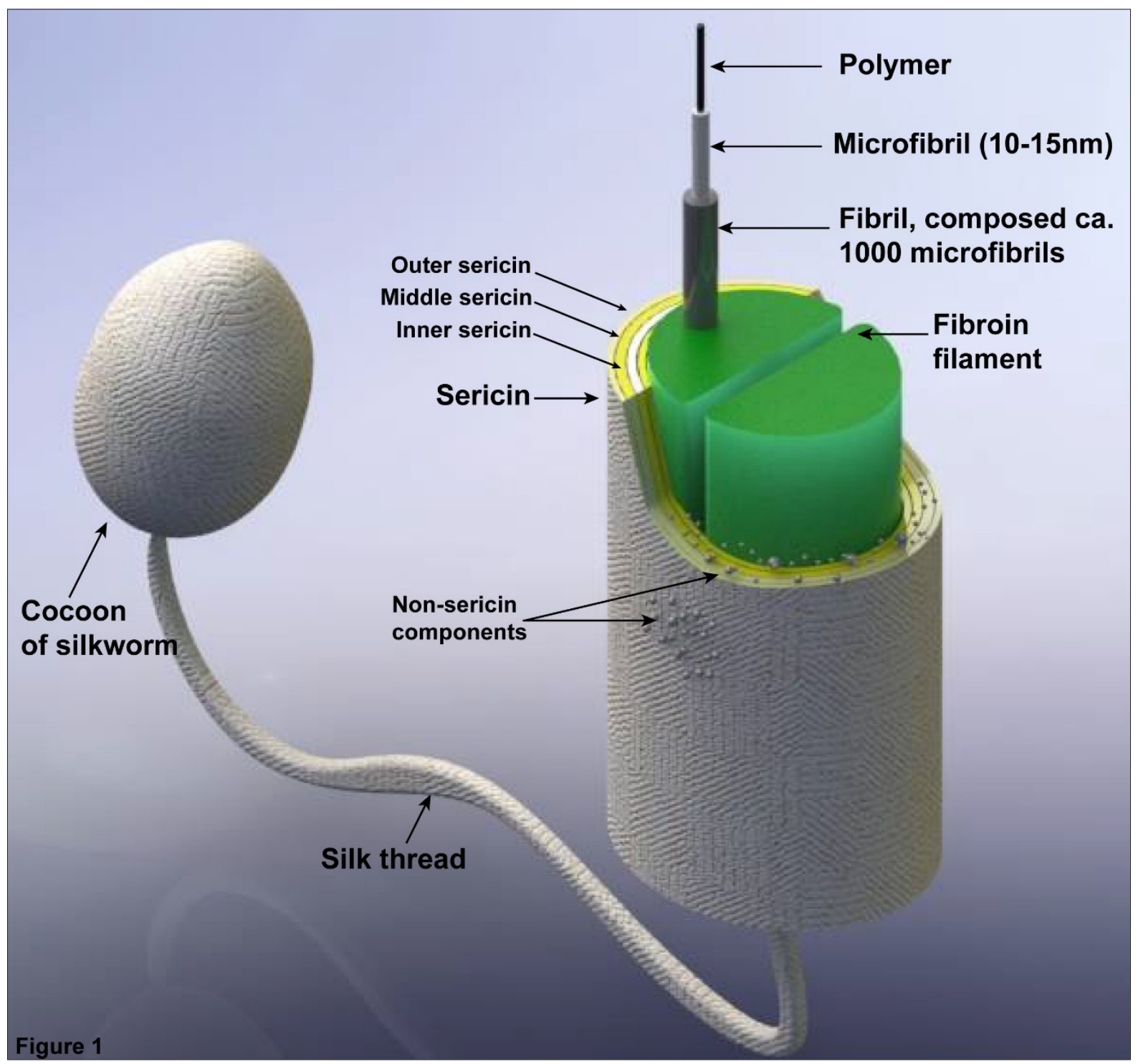

Figure 1: Schematic structure of a silk thread in the silkworm cocoon. Image modified from [11,28,119]..

In the B. Mori worm, the structure of heavy-chain fibroin (H-fibroin) is hydrophobic, rich in glycine, and exhibits a hierarchical layout of repeated GAGAGS motifs [21-25] that self-assemble into anti-parallel $\beta$-sheets; these structures are highly crystalline and crosslink the protein via hydrogen bonds and van der Waals interactions between $\beta$-sheets, conferring robust mechanical properties [26]. Light-chain fibroin (L-fibroin) is predominantly hydrophobic and elastic, whereas P25 consists of an alternating sequence of hydrophobic and hydrophilic regions [20,22,27].

SF is a polymorphic protein, and 3 different types of structural arrangements have been described to date: silk I [28-30], silk II ( $\beta$-sheets) $[23,31]$, and silk III $[32,33]$. These structures depend on environmental conditions, such as the temperature, $\mathrm{pH}$, solvents [34], and concentrations of solutions.

The sequence of amino acids influences the structural properties of fibroin $[17,24,35]$. In silk II, alanine and serine affect the rigidity of $\beta$-sheets; alanine provides stability to the sheets, whereas serine is responsible for hydrophobicity [36]. A recent study of the differences in the structural characteristics and properties of cocoons produced by varieties of $B$. mori concluded that the molecular weight of regenerated SF, viscosity in solution, and mechanical properties depended on the variety of the silkworm [37]; however, months later, Jang et al. [38] reported that the differences observed in mechanical properties could be attributed to the techniques used to measure them, such as wet spinnability [38].

Although the structural characteristics and polymer properties depend on the specific variety of silkworm, the silkworm variety is rarely considered in biomedical applications. Despite the diversity in the composition of these silks, these biomaterials tend to have similar functionality.

\section{SF; Suitable features for biomedical applications}

The use of biomaterials for scaffolding purposes is a fundamental component of TE efforts to replace injured tissue with functional reconstructed tissue. Ideal scaffolding biomaterials 
should support cellular adhesion and migration; promote cell-cell interaction, proliferation, and differentiation; be biocompatible; exhibit controlled biodegradation; match the growth rate of the newly formed tissue; and be processed such that it supports structural and morphological modifications suitable for the needs of the native tissue [39]. Numerous studies have demonstrated that $\mathrm{SF}$ is according to these requirements, moreover, SF possesses key features for $\mathrm{OC}$ tissue: mechanical elasticity and resistance.

\section{Biocompatibility}

In 1993, the Food and Drug Administration (FDA) recognized SF as a biomaterial due to its prolific use in sutures. Two years later, SF was studied for the first time to test its adhesive and cellular growth capabilities by cultivating fibroblasts in matrices formed from the SF of B. mori [40]. Scaffolds fabricated from SF generally lack sericin; it tends to be discarded in biomedical uses because it may produce an allergic reaction [41,42]; however, recent studies have demonstrated it to be safe for biomedical uses $[18,43]$, illustrating that it better promotes cellular adhesion than fibroin, among other superior qualities [44]. Additionally, Liu et al [45]. show that immunogenicity does not significantly differ between SFs and sericin.

SF has been used both in raw form and in combination with other biomaterials to optimize the characteristics of each combination and create more efficient scaffoldings for biomedical uses. One such combination consists of SF and chitosan; this combination is biocompatible and permits the growth and migration of mesenchymal stem cells (MSC) on a 3D scaffold [7,46]. A later study by Vishwanath et al. [47] tested different proportions of SF and chitosan, concluding that a respective 80:20 ratio provided the best conditions for cartilage regeneration using MSCs derived from umbilical cord blood. Samal et al. [48] also tested this combination of biomaterials, using ultrasonics to eliminate the use of organic solvents or chemical crosslinking during the production of $3 \mathrm{D}$ SF hydrogels. This combination has also been shown to support chondrogenic phenotypes in 3D scaffolds [49]. Tamada et al. [50] used 3D SF scaffolds that were also biocompatible for the growth of MC3T3 cells. One unique characteristic of the SF molecule is the presence of 2 different active sequences, VITTDSDGNE and NINDFDED, both of which are recognized by an integrin. Combined with the ability to promote cellular growth, this characteristic endows SF with the capability of biorecognition [51].

MG-63 [52] cells, mesenchymal stem cells derived from bone marrow (BMSC) [53-56], mesenchymal stem cells derived from adipose tissue (ADSC) [57], chondrocytes [58-60] (including immortalised chondrocytes) [61], nucleus pulposus cells [62], and fibroblasts [63] have also been cultivated in SF-based scaffolds.

Another intriguing combination was studied by Jaipaew et al. [64], who combined SF with hyaluronic acid (HA) and obtained elastic scaffolds; the cells grown on these scaffolds showed the ability to express chondrogenic markers. Li et al. [65] obtained similar results, producing nanofibre scaffolds by electrospinning SF with poly(L-lactic-acid). Other materials that have been used in combination with SF to create scaffolds include agarose [66], type II collagen (col II) [67], type I collagen (col I) [68], and hydroxyapatite (Hap) [69]. The biocompatibility of SF has also been demonstrated in applications associated with the repair of bone [70-77], meniscus [78], skin [79], and tendon defects [3].

\section{Structural designsof SF-based biomaterials}

SF is easy to chemically modify and can later be processed into various forms, such as fibres, gels, films, microspheres, tubes, and sponges (aqueous or with organic solvents) [19,80]. Moreover, 3D biomaterials should provide appropriate mechanical properties, such as a porosity, size, orientation, and interconnectivity between pores specific to tissue type; the ability to culture cells on these biomaterials is equally important.

Despite the existence of different techniques for processing SF, the methods most utilized for developing 3D scaffolds to repair cartilage and bone are HFIP-sponges (1,1,1,3,3,3-hexafluoro-2propanol; HFIP), aqueous sponges, and electrospinning-derived fibres. Electrospinning can produce small-diameter, large-surface area fibres, which yield a nonwoven isotropic mat of silk fibres. SF sponges possess porous 3D scaffolds; aqueous sponges exhibit excellent interconnectivity between pores and can incorporate bioactive molecules, whereas HFIP-sponges have smooth pore surfaces and greater mechanical resistance, the latter of which can be increased by adding reinforcing agents [80].

One valuable advantage of SF in creating 3D scaffolds is pore size modulation. Kim et al. [81] developed 3D scaffolds derived from aqueous fibroin using $\mathrm{NaCl}$ particles of different size for pore formation and observed that salt particles between 470 and $940 \mu \mathrm{m}$ yielded highly homogenous and interconnected pores. Similar results were obtained by Wang et al. [82] for 3D fibroin scaffolds using $500-1000 \mu \mathrm{m}$ salt particles; subsequent to the biological characterization of the scaffolding, they observed high expression levels of chondrogenic genes as well as abundant cartilaginous extracellular matrix (ECM) production. Conversely, Han et al. [83] suggest that the use of $90-180 \mu \mathrm{m}$ salt particles affords a better environment for chondrocyte adhesion and proliferation, yielding an ECM rich in glycosaminoglycans (GAGs) and type II collagen.

In addition to $\mathrm{NaCl}$, other types of particles have been used to promote porogenesis. For example, Moon et al. [84] used a mix of $\mathrm{NaCl}$ and sucrose as a porogen to generate 3D scaffolds with different characteristics and suggested that these scaffolds were applicable for TE. Makaya et al. [85] compared SF-based scaffolds derived from combinations of $\mathrm{NaCl} /$ water and sucrose/HFIP, using particles that varied between 300 and $500 \mu \mathrm{m}$ in size. The $\mathrm{NaCl} /$ water combination yielded an average pore size of $108.2 \mu \mathrm{m}$ and produced much more resistance in compression tests than sucrose/HFIP, which resulted in an average pore size was $329.8 \mu \mathrm{m}$. Importantly, this study could not definitively attribute the results to either the porogen or the solvent used. In another study, Nazarov et al. [86] used ammonium bicarbonate particles as porogens and gas foaming to produce 3D scaffolds, noting high resistance to compressive forces and interconnected pores greater than $100 \mu \mathrm{m}$ in diameter. 
One of the challenges in creating OC scaffolds is in the union of 2 different biomaterials. To solve this problem, Foss et al. [87] recommend the use of genipin as a natural crosslinker for forming $\mathrm{HA}$ and SF sponges because these materials remained joined, unlike other spongers that were not created using this crosslinker. Moreover, Zhou et al. [88] attribute to genipin higher mechanical properties when is used as a crosslinker in silk fibroinchondroitinsulfate scaffolds, due to it provides positively charged amino groups that could adsorb chondroitin sulfate through electrostatic interaction.

\section{Degradation rate}

According to the definitions of the United States Pharmacopeia, SF-based sutures are not considered degradable because the suture maintains $50 \%$ of its tension in vivo after 60 days. However, the literature demonstrates that SF is generally degradable over prolonged periods in vivo despite the existence of multiple forms and processing techniques $[41,89,90]$. Essentially, SF has been shown to induce a mild inflammatory response in vivo. Specifically, activating macrophages detect SF as a foreign body, which promotes the formation of multinucleated giant cells [16]. The immune response depends on the structure, implantation site, and fabrication method of the SF materials.

SF degradation can be affected by several factors, including the fabrication method, and can last from hours to years. For example, in vivo aqueous SF scaffolds degrade quickly (2-6 months) because their hydrophilicity make them more susceptible to enzymatic degradation, whereas scaffolds derived from HFIP degrade much more slowly (1 year) due to their hydrophobic nature [91].

As mentioned previously, biomaterials should degrade at rates like the formation of new tissue to restore physiological function. This requirement necessitates a fundamental understanding of the interactions between physiological factors, such as the routine mechanical loads that each tissue is subject to under physiological conditions, and the effect that these factors have on biomaterial degradation. Kluge et al. [92] developed an experimental mathematical model to characterize the degradation of silk fibres produced after enzymatic treatment ( $\alpha$-chymotrypsin or protease XVI) combined with cyclic loading and unloading to elucidate degradation and develop effective, future clinical applications [92]. Summarizing the above observations, SF was initially demonstrated to be a biomaterial with adequate characteristics for use in biomedical applications, and the selection of the system of dilution used was shown to be critical for the degradation of SF.

\section{Scaffolds based on fibroin for the repair of OCDs}

Articular cartilage is a type of connective tissue [93] responsible for distributing loads over the entire joint surface [94]. However, its natural lack of vasculature and the low mobility of its component cells, i.e., chondrocytes, confer limited self-repair capabilities [95], and severe trauma to joints not only produces lesions in the cartilage but may also extend damage to the subchondral bone, resulting in osteochondral defects (OCDs) [96]. These characteristics make cartilage an ideal candidate for cartilage tissue engineering (TE).
Although initial attempts at cartilage reconstruction focused on regenerating superficial layers $[97,98]$, without taking into account subchondral tissue, recent studies have explored the biomechanical structure and properties of osteochondral (OC) tissue to develop biomimetic scaffolds that can imitate the patterns of natural structures in tissue and improve integration and regeneration $[99,57,100]$.

An OCD compromises articular cartilage, subchondral bone, and interphase tissue to affect joint mechanics and create degenerative changes [101]. The creation of scaffolds that can restore normal function to an OCD is complex due to differences in the composition and structure of each segment as well as the mechanical and biochemical needs that must be considered at each phase. Taking into account these requirements, OC scaffolds should generate biomimetic structures that can incorporate bioactive materials that significantly influence osteogenesis and/or chondrogenesis and obtain mechanical and biochemical characteristics similar to those of tissue.

Strategies for constructing OC scaffolds have improved over the years, and Li et al. [102] classify these strategies into the following categories: monophasic scaffolds, osseous phase scaffolds with cells in the chondral phase, an ensemble of scaffolds with both osseous and chondral phases pre-cultured separately, homogenous scaffolds with different cell populations at each phase, homogeneous scaffolds with a continuous gradient of bioactive molecules for one or both phases, and individual scaffolds with chondral and osseous phases integrated during their fabrication.

Three-dimensional porous SF-based scaffolds have been proposed to emulate the collagen fibril network of normal cartilage ECM, where, the porosity in the phases of the scaffolds is critical to achieve efficient OC regeneration. In general, small pores in the chondral phase are desired to induce hypoxia and favour chondrogenesis $[103,104]$, whereas larger pores are more desirable in the osseous phase $[105,106]$ to promote angiogenesis; this different structures simulates physiological conditions, however there are recent designs that propose opposite $[107,108]$. Furthermore, chondrogenic or osteogenic differentiation is influenced not only by the size of the pore but also by the assembly strategy, the starting cell type, and the culture conditions (Table 1).

Table 1 summarizes the 3D, SF-based scaffolds developed for OC TE applications. Notably, new studies are on-target to develop co-culturing systems that better emulate the native characteristics of each phase of OC tissue. These differences, i.e., modelling the regenerative niche in stratified tissue, such as $\mathrm{OC}$ tissue, represent the greatest challenge in the development of biomaterials. The development of co-culture systems seeks to take advantage of heterotopic cellular communication, that is, the capacity of cells from different lines to mutually influence their functions and, ultimately, simulate the native niche [109]. Despite the complexity represented in the development of in vitro co-cultures, they are expected to be the most promising clinical option for treating $\mathrm{OC}$ lesions. 


\begin{tabular}{|c|c|c|c|c|c|c|c|c|c|c|c|}
\hline & \multicolumn{5}{|c|}{ Chondral } & \multicolumn{4}{|c|}{ Osseous } & & \\
\hline $\begin{array}{l}\text { Refer- } \\
\text { ence }\end{array}$ & $\begin{array}{c}\# \\
\text { Phases }\end{array}$ & Material & $\begin{array}{c}\text { Pore } \\
\text { size/ } \\
\text { Pore for- } \\
\text { mation } \\
\text { tech- } \\
\text { nique }\end{array}$ & $\begin{array}{l}\% \text { Po- } \\
\text { rosity }\end{array}$ & $\begin{array}{l}\text { Cellular } \\
\text { source }\end{array}$ & Material & $\begin{array}{c}\text { Pore } \\
\text { size/ } \\
\text { Pore for- } \\
\text { mation } \\
\text { tech- } \\
\text { nique }\end{array}$ & $\begin{array}{c}\text { \% Poros- } \\
\text { ity }\end{array}$ & $\begin{array}{l}\text { Cellular } \\
\text { source }\end{array}$ & $\begin{array}{l}\text { Culture } \\
\text { conditions }\end{array}$ & $\begin{array}{l}\text { Assem- } \\
\text { bly }\end{array}$ \\
\hline$[113] \neq$ & 2 & SF & $\begin{array}{l}300- \\
425 \mu \mathrm{m} \\
\text { /Par- } \\
\text { ticulate } \\
\text { leaching } \\
\text { (NaCl) }\end{array}$ & $95.50 \%$ & BMSC & SF & $\begin{array}{l}300- \\
425 \mu \mathrm{m} / \\
\text { Partic- } \\
\text { ulate } \\
\text { leaching } \\
(\mathrm{NaCl})\end{array}$ & $95.50 \%$ & BMSC & $\begin{array}{l}\text { Pre-culture } \\
\text { separately in } \\
\text { each phase of } \\
\text { the scaffold } \\
\text { with control } \\
\text { medium (static } \\
\text { culture) and } \\
\text { later change to } \\
\text { CM or OM (dy- } \\
\text { namic culture). } \\
\text { Co-c in biore- } \\
\text { actors after } \\
\text { the assembly } \\
\text { of both phases } \\
\text { with OM, CM } \\
\text { or control } \\
\text { medium. }\end{array}$ & Suture \\
\hline $\begin{array}{c}\text { Chen } \\
{[119] \ddagger}\end{array}$ & 2 & $\mathrm{SF}$ & $\begin{array}{c}150 \mu \mathrm{m} / \\
\text { Freeze-ly- } \\
\text { ophiliza- } \\
\text { tion }\end{array}$ & NA & BMSC & $\mathrm{SF}$ & $\begin{array}{c}150 \mu \mathrm{m} / \\
\text { Freeze-ly- } \\
\text { ophiliza- } \\
\text { tion }\end{array}$ & NA & Osteoblast & $\begin{array}{c}\text { Pre-culture } \\
\text { separately in } \\
\text { each phase of } \\
\text { the scaffold } \\
\text { with respective } \\
\text { CM or OM. Co-c } \\
\text { after assembly. }\end{array}$ & $\begin{array}{l}\text { RADA } \\
\text { peptide }\end{array}$ \\
\hline $\begin{array}{l}\text { Saha } \\
{[96] \neq Y ́}\end{array}$ & 3 & $\begin{array}{c}\text { SF Mulber- } \\
\text { ry or no } \\
\text { Mulberry + } \\
\text { TGF- } \beta 3\end{array}$ & $\begin{array}{l}\text { Mulberry } \\
72 \mu \mathrm{m} ; \\
\text { No-Mul- } \\
\text { berry } \\
74 \mu \mathrm{m} / \\
\text { Freeze-ly- } \\
\text { ophiliza- } \\
\text { tion }\end{array}$ & $74-82 \%$ & $\begin{array}{l}\text { In vivo: } \\
\text { BMSC; } \\
\text { In vitro: } \\
\text { NC }\end{array}$ & $\begin{array}{c}\text { SF mul- } \\
\text { berry o no } \\
\text { mulberry } \\
\text { + BMP2 }\end{array}$ & $\begin{array}{l}\text { Mulberry } \\
72 \mu \mathrm{m} ; \\
\text { No-Mul- } \\
\text { berry } \\
74 \mu \mathrm{m} / \\
\text { Freeze-ly- } \\
\text { ophiliza- } \\
\text { tion }\end{array}$ & $74-82 \%$ & $\begin{array}{c}\text { In vivo: } \\
\text { BMSC } \\
\text { In vitro: } \\
\text { NC }\end{array}$ & $\begin{array}{l}\text { In vitro: dy- } \\
\text { namic cultures } \\
\text { on scaffolds } \\
\text { without sepa- } \\
\text { rated induction } \\
\text { media, later } \\
\text { with CM or OM } \\
\text { In vivo: NC }\end{array}$ & $\begin{array}{l}\text { Fibrin } \\
\text { glue } \\
\text { only } \\
\text { prior to } \\
\text { implan- } \\
\text { tation in } \\
\text { vivo }\end{array}$ \\
\hline $\begin{array}{l}\text { Chen } \\
{[120] \ddagger}\end{array}$ & 2 & SF & $\begin{array}{c}150 \mu \mathrm{m} \\
\text { /lyo- } \\
\text { philiza- } \\
\text { tion }\end{array}$ & NA & BMSC & SF & $\begin{array}{l}150 \mu \mathrm{m} / \\
\text { Lyo- } \\
\text { philiza- } \\
\text { tion to } \\
\text { form } \\
\text { pores }\end{array}$ & NA & BMSC & $\begin{array}{c}\text { Pre-culture } \\
\text { separately on } \\
\text { the scaffold } \\
\text { with respective } \\
\mathrm{CM} \text { or OM. Co-c } \\
\text { after assembly }\end{array}$ & $\begin{array}{l}\text { RADA } \\
\text { Peptide, } \\
\text { self-as- } \\
\text { sembly }\end{array}$ \\
\hline $\begin{array}{c}\text { Yan } \\
{[114] \neq Y ́}\end{array}$ & 2 & $\mathrm{SF}$ & $\begin{array}{c}300- \\
700 \mu \mathrm{m} / \\
\text { Partic- } \\
\text { ulate } \\
\text { leaching } \\
(\mathrm{NaCl})\end{array}$ & $82.02 \%$ & $\begin{array}{l}\text { BMSC } \\
\text { only for } \\
\text { charac- } \\
\text { teriza- } \\
\text { tion in } \\
\text { vitro }\end{array}$ & $\begin{array}{l}\text { Silk-nano- } \\
\text { CaP }\end{array}$ & $\begin{array}{l}300- \\
700 \mu \mathrm{m} / \\
\text { Partic- } \\
\text { ulate } \\
\text { leaching } \\
(\mathrm{NaCl})\end{array}$ & $62.27 \%$ & $\begin{array}{c}\text { BMSC only } \\
\text { for charac- } \\
\text { terization } \\
\text { in vitro }\end{array}$ & $\begin{array}{l}\text { In vivo: NC for } \\
\text { implants in } \\
\text { OCD lesions }\end{array}$ & $\begin{array}{l}\text { Lyo- } \\
\text { philiza- } \\
\text { tion }\end{array}$ \\
\hline
\end{tabular}




\begin{tabular}{|c|c|c|c|c|c|c|c|c|c|c|c|}
\hline $\begin{array}{l}\text { Ding } \\
57 \neq\end{array}$ & 3 & SF & $\begin{array}{c}112.4 \mu \mathrm{m} \\
\text { / Par- } \\
\text { ticulate } \\
\text { leaching } \\
(\mathrm{NaCl})\end{array}$ & $85.30 \%$ & ADSC & $\mathrm{SF} / \mathrm{Hap}$ & $\begin{array}{c}362.2 \mu \mathrm{m} \\
\text { / Par- } \\
\text { ticulate } \\
\text { leaching } \\
(\mathrm{NaCl})\end{array}$ & $90.25 \%$ & ADSC & $\begin{array}{l}\text { Pre-culture } \\
\text { separately in } \\
\text { monolayer with } \\
\text { CM or OM and } \\
\text { subsequent cul- } \\
\text { ture separately } \\
\text { in each phase } \\
\text { of the scaffold } \\
\text { with CM or OM. }\end{array}$ & $\begin{array}{l}\text { TIPS } \\
\text { Tech- } \\
\text { nique }\end{array}$ \\
\hline $\begin{array}{l}\text { Ghezzi } \\
{[117] \neq}\end{array}$ & 3 & $\begin{array}{l}\text { HybridCol } \\
\text { I-SF-Col I }\end{array}$ & NA & NA & BMSC & $\begin{array}{c}\text { Hybrid } \\
\text { Col I-SF- } \\
\text { Col I }\end{array}$ & NA & NA & BMSC & $\begin{array}{l}\text { Cells were } \\
\text { seeded in the } \\
\text { hybrid and } \\
\text { each phase } \\
\text { separately with } \\
\text { non-differenti- } \\
\text { ation medium, } \\
\text { CM and OM for } \\
\text { each }\end{array}$ & $\begin{array}{l}\text { PC Tech- } \\
\text { nique }\end{array}$ \\
\hline $\begin{array}{c}\mathrm{Li} \\
{[102] \ddagger}\end{array}$ & 2 & SF & $\begin{array}{c}100- \\
120 \mu \mathrm{m} / \\
\text { Freezin- } \\
\text { gat }-20^{\circ} \\
\text { C }\end{array}$ & NA & BMSC & SHG-slk & $\begin{array}{c}400- \\
500 \mu \mathrm{m} / \\
\text { PSM }\end{array}$ & NA & BMSC & $\begin{array}{l}\text { Cells were } \\
\text { grown in both } \\
\text { phases of } \\
\text { the scaffold } \\
\text { and cultured } \\
\text { as biphasic } \\
\text { or separate } \\
\text { phases with MC } \\
\text { and OM }\end{array}$ & $\begin{array}{l}\text { lyo- } \\
\text { philiza- } \\
\text { tion }\end{array}$ \\
\hline $\begin{array}{l}\text { Chen } \\
{[112] \ddagger}\end{array}$ & 2 & SF & $\begin{array}{l}\text { NA / } \\
\text { Freeze- } \\
\text { lyo- } \\
\text { philiza- } \\
\text { tion }\end{array}$ & NA & BMSC & SF & $\begin{array}{l}\text { NA / } \\
\text { Freeze- } \\
\text { lyo- } \\
\text { philiza- } \\
\text { tion }\end{array}$ & NA & BMSC & $\begin{array}{c}\text { Cultivation in } \\
\text { chambers for } \\
\text { co-cultivation } \\
\text { with CM or OM } \\
\text { medium for } \\
\text { each compart- } \\
\text { ment }\end{array}$ & $\begin{array}{l}\text { RADA } \\
\text { Peptide, } \\
\text { self-as- } \\
\text { sembly }\end{array}$ \\
\hline $\begin{array}{l}\text { Çakmak } \\
{[115] \neq}\end{array}$ & 3 & $\begin{array}{c}\text { Hidro- } \\
\text { gel-PA-RGDS }\end{array}$ & NA & NA & $\begin{array}{l}\text { Chon- } \\
\text { dro- } \\
\text { cytes }\end{array}$ & Silk-Hap & $\begin{array}{c}240- \\
585 \mu \mathrm{m} / \\
\text { Partic- } \\
\text { ulate } \\
\text { leaching } \\
\text { ( } \mathrm{NaCl})\end{array}$ & $90 \%$ & BMSC & $\begin{array}{l}\text { BMSC were } \\
\text { grown on the } \\
\text { silk scaffold } \\
\text { with OM and } \\
\text { chondrocytes } \\
\text { were cultured } \\
\text { in hydro- } \\
\text { gels-PA-RGDS } \\
\text { with CM, sepa- } \\
\text { rately. } \\
\text { Subsequent } \\
\text { assembly } \\
\text { and Co-c in } \\
\text { osteochondral } \\
\text { medium }\end{array}$ & $\begin{array}{l}\text { Through } \\
\text { an } \\
\text { acellular } \\
\text { SF in- } \\
\text { terface, } \\
\text { the MEC } \\
\text { secreted } \\
\text { by the } \\
\text { cells in } \\
\text { each } \\
\text { phase } \\
\text { helped } \\
\text { to } \\
\text { self-ad- } \\
\text { hesion }\end{array}$ \\
\hline
\end{tabular}

It is notable that new research is aimed at developing co-culture systems that allow better emulation of the native characteristics in each phase of the osteochondral tissue. Modeling the "regenerative niche" in tissue stratified as the OC tissue represents the greatest challenge in the development of biomaterials. The application of co-culture systems is based on heterotypic cellular communication, this ability of cells of different strains, to mutually influence their functions and simulate the native niche [109]. Thus, Ribeiro et al. [110] in their recent study investigated cell behavior in the complete osteochondral grafts through a chondrocytes and osteoblasts coculture system, even though the established co-culture system showed the possibility of maintaining for long-term the co-culture of each cell line, the results indicated that the proposed coculture model may have the potential to induce chondrocytes prehypertrophy, so the use of chambers is suggested.
As mentioned, most SF-based osteochondral scaffold designs are initially cultured in differentiation inducing media separately for each phase, in contrast, some designs use techniques involving compression [111], lyophilization [102] or temperature gradient [57] to interleave the phases before performing the initial culture. This improves the integration, however, despite having an integrated scaffold, the ability to support differentiation (chondrogenic and osteogenic) is still evaluated in the separated phases instead the interlaced. Recently Chen et al. [112] developed chambers for co-culture, thus allowing the coordinated differentiation of the chondrogenic and osteogenic phenotype. Equally important is the recent research by Liu et al. [113] which achieve isolate the cartilage phase from bone phase developing a layer that mimics the osteochondral tissue calcified layer, being permeable to some molecules with limited molecular weight and able to prevent the 
seeded cells from migrating cross the unit when being grown in chambers.

It has been observed that the use of bioactive molecules improves osteochondral differentiation. Saha et al. [96] added TGF- $\beta 3$ in the chondral phase and BMP2 in the bone phase of FSbased osteochondarl scaffolds, these bioactive molecules induce chondrogenic and osteogenic differentiation, respectively, even when implanted cell-free in femoral Wistar rats. Their results further confirm that depending on the variety of silkworm used to influence the efficiency to route the cells to the chondrogenic or osteogenic phenotype both in vivo and in vitro. In addition, osteoconductors have been used, such as calcium phosphate [114], Hap [57,115] and strontium-hardystonite-gahnite [102], incorporated into the bone phase of osteochondral scaffolds resulting in better osteogenesis and superior mechanical properties. For example, Ruan et al. [108] achieved high levels of collagen I gene expression incorporating Hap in the phase that mimics bone although the scaffold was cultured in non-osteogenic medium.

Ideally for rapid clinical application would be that the scaffold, alone, without cellular additives or bioactive molecules would be able to influence the chondrogenic and osteogenic process of the OC tissue to restore the native physiological functions [116]. A small number of FS-based OC scaffolds are evaluated by in vivo models [96,114], although the results appear to be promising, future research should focus on models where load and joint design resemble the human (horse, pig, sheep) [117-120].

\section{Conclusion and Future Directions}

SF as biomaterial is promising for the construction of osteochondral scaffolds due to its good biocompatibility, versatile processing, and varied sterilization options and to support chondrogenic and osteogenic differentiation. Satisfying the physical, biological and mechanical requirements of OC tissue is complicated due to its stratified nature but approaches in the field of tissue engineering and co-culture have achieved promising biomimetic approaches for a possible short-term clinical application.

We consider that the next big step that SF-based chondral and OC scaffolds must give is their application by in vivo models; especially in models that represent a challenge for its design and for the potential for chondral and osteochondral regeneration, a characteristic that has been attributed to it throughout its in vitro evaluations and that, unlike other biomaterials, in vivo evaluations are scarce. Additionally, most of the models used rarely simulate the native design and mechanical needs of the human joint. In order to accelerate the transfer of the multi-phases grafts to the medical area, clinical practice requirements must be taken into account; the direction to achieve this requires greater efforts in a simplified manufacturing, reproducibility of the technique, storage conditions and sterility methods.

The development of scaffolds and physical, biological and mechanical characterization is a multidisciplinary work, so it is essential that ongoing advances in every branch converge to achieve far-reaching results clinically to restore normal functions of osteochondral tissue.

\section{Conflict of Interests}

The authors declare that there is no conflict of interests regarding the publication of this paper.

\section{Authors' Contribution}

All authors were involved in drafting the paper, and all authors approved the final version to be published.

\section{Acknowledgment}

We are grateful to IE. Alejandra Córdoba Pérez for her valuable help with the figure design. This work has been partially financed by CONACyT; 233365-SALUD/2014

\section{References}

1. Zhao C, Asakura T (2001) Structure of silk studied with NMR. Prog Nucl Magn Reson Spectrosc 39(4): 301-352.

2. Li G, Li Y, Chen G, He J, Han Y, et al. (2015) Silk-based biomaterials in biomedical textiles and fiber-based implants. Adv Healthc Mater 4(8): 1134-1151.

3. Hennecke K, Redeker J, Kuhbier JW, Strauss S, Allmeling C, et al. (2013) Bundles of spider silk, braided into sutures, resist basic cyclic tests: potential use for flexor tendon repair. PLoS One 8(4): e61100.

4. Gimenes ML, Silva VR, Vieira MG, Silva MC, Scheer AP, et al. (2014) High molecular sericin from bombyx mori cocoons: extraction and recovering by ultrafiltration. Int J Chem Eng Appl 5(3): 266-271.

5. Wang P, Qi C, Yu Y, Yuan J, Cui L, et al. (2015) Covalent immobilization of catalase onto regenerated silk fibroins via tyrosinase-catalyzed crosslinking. Appl Biochem Biotechnol 177(2): 472-485.

6. Ju HW, Lee OJ, Lee JM, Moon BM, Park HJ, et al. (2015) Wound healing effect of electrospun silk fibroin nanomatrix in burn-model. Int J Biol Macromol 85: 29-39.

7. Altman AM, Gupta V, Ríos CN, Alt EU, Mathur AB (2010) Adhesion, migration and mechanics of human adipose-tissue-derived stem cells on silk fibroin-chitosan matrix. Acta Biomater 6(4): 1388-1397.

8. Bai S, Han H, Huang X, Xu W, Kaplan DL, et al. (2015) Silk scaffolds with tunable mechanical capability for cell differentiation. Acta Biomater 20: 22-31.

9. Dong Y, Dong P, Huang D, Mei L, Xia Y, et al. (2015) Fabrication and characterization of silk fibroin-coated liposomes for ocular drug delivery. Eur J Pharm Biopharm 91: 82-90.

10. Mwangi TK, Bowles RD, Tainter DM, Bell RD, Kaplan DL, et al. (2015) Synthesis and characterization of silk fibroin microparticles for intraarticular drug delivery. Int J Pharm 485(1-2): 7-14.

11. Germershaus O, Werner V, Kutscher M, Meinel L (2014) Deciphering the mechanism of protein interaction with silk fibroin for drug delivery systems. Biomaterials 35(10): 3427-3434.

12. Gil ES, Frankowski DJ, Spontak RJ, Hudson SM (2005) Swelling behavior and morphological evolution of mixed gelatin/silk fibroin hydrogels. Biomacromolecules 6(6): 3079-3087.

13. Kim DW, Lee OJ, Kim SW, Ki CS, Chao JR, et al. (2015) Novel fabrication of fluorescent silk utilized in biotechnological and medical applications. Biomaterials 70: 48-56.

14. Teramoto H, Kojima K (2014) Production of bombyx mori silk fibroin incorporated with unnatural amino acids. Biomacromolecules 15(7): $2682-2690$

15. Burke KA, Roberts DC, Kaplan DL (2017) Silk fibroin aqueous-based adhesives inspired by mussel adhesive proteins. Biomacromolecules 17(1): 237-245. 
16. Chung DE, Kim HH, Kim MK, Lee KH, Park YH, et al. (2015) Effects of different Bombyx mori silkworm varieties on the structural characteristics and properties of silk. Int J Biol Macromol 79: 943-951.

17. Malay AD, Sato R, Yazawa K, Hiroe, Nao Ifuku, et al. (2016) Relationships between physical properties and sequence in silkworm silks. Sci Rep.

18. Cao TT, Zhang YQ (2016) Processing and characterization of silk sericin from bombyx mori and its application in biomaterials and biomedicines. Mater Sci Eng C 61(2-3): 940-952.

19. Vepari C, Kaplan DL (2007) Silk as a biomaterial. Prog Polym Sci 32(8-9): 991-1007.

20. Aznar SD, Vicente CD, Meseguer OL, Cenis JL, Lozano AA (2013) Influence of the protocol used for fibroin extraction on the mechanical properties and fiber sizes of electrospun silk mats. Mater Sci Eng C 33(4): 19451950.

21. Zurovec M, Yonemura N, Kludkiewicz B, František, Dalibor, et al. (2016) Sericin composition in the silk of antheraea yamamai. Biomacromolecules 17(5): 1776-1787.

22. Sehnal F, Žurovec M (2004) Construction of silk fiber core in lepidoptera. Biomacromolecules 5(3): 666-674.

23. Wilson D, Valluzzi R, Kaplan D (2000) Conformational transitions in model silk peptides. Biophys J 78(5): 2690-2701.

24. Fedic R, Zurovec M, Sehnal F (2003) Correlation between fibroin amino acid sequence and physical silk properties. J Biol Chem 278(37): 3525535264.

25. Zhou CZ, Confalonieri F, Jacquet M, Perasso R, Li ZG, et al. (2001) Silk fibroin: Structural implications of a remarkable amino acid sequence. Proteins Struct Funct Genet 44(2): 119-122.

26. Murphy AR, Kaplan DL (2009) Biomedical applications of chemicallymodified silk fibroin. J Mater Chem 19(36): 6443.

27. Fedic R, Zurovec M, Sehnal F (2002) The silk of lepidoptera. J Insect Biotechnol Sericology 71: 1-15.

28. He SJ, Valluzzi R, Gido SP (1999) Silk I structure in bombyx mori silk foams. Int J Biol Macromol 24(2-3): 187-195.

29. Asakura T, Ashida J, Yamane T, Kameda T, Nakazawa Y, et al. (2001) A repeated beta-turn structure in poly (Ala-Gly) as a model for silk I of Bombyx mori silk fibroin studied with two-dimensional spin-diffusion NMR under off magic angle spinning and rotational echo double resonance. J Mol Biol 306(2): 291-305.

30. Ming J, Pan F, Zuo B (2015) Influence factors analysis on the formation of silk I structure. Int J Biol Macromol 75: 398-401.

31. Hino T, Tanimoto M, Shimabayashi S (2003) Change in secondary structure of silk fibroin during preparation of its microspheres by spray-drying and exposure to humid atmosphere. J Colloid Interface Sci 266(1): 68-73.

32. Valluzzi R, He SJ, Gido SP, Kaplan D (1999) Bombyx mori silk fibroin liquid crystallinity and crystallization at aqueous fibroin organic solvent interfaces. Int J Biol Macromol 24(2-3): 227-236.

33. Valluzzi R, Gido SP, Muller W, Kaplan DL (1999) Orientation of silk III at the air-water interface. Int J Biol Macromol 24(2-3): 237-242.

34. Li M, Tao W, Kuga S, Nishiyama Y (2003) Controlling molecular conformation of regenerated wild silk fibroin by aqueous ethanol treatment. Polym Adv Technol 14(10): 694-698.

35. Zhang L, Bai Z, Ban H, Liu L (2015) Effects of the amino acid sequence on thermal conduction through $\beta$-sheet crystals of natural silk protein. Phys Chem Chem Phys 17(43): 29007-29013.

36. Carrascoza JF, Lupan A, Cosar C, Kun AZ, Silaghi D, et al. (2015) On the roles of the alanine and serine in the $\beta$-sheet structure of fibroin. Biophys Chem 197:10-17.
37. Grogan SP, Miyaki S, Asahara H, D’Lima DD, Lotz MK (2009) Mesenchymal progenitor cell markers in human articular cartilage: normal distribution and changes in osteoarthritis. Arthritis Res Ther 11(3): R85.

38. Jang MJ, Um IC (2015) Effect of different bombyx mori silkworm varieties on the wet spinning of silk fibroin. Int J Ind Entomol 30(2): 75-80.

39. Wang Y, Kim HJ, Vunjak G, Kaplan DL (2006) Stem cell-based tissue engineering with silk biomaterials. Biomaterials 27(36): 6064-6082.

40. Melke J, Midha S, Ghosh S, Ito K, Hofmann S (2016) Silk fibroin as biomaterial for bone tissue engineering. Acta Biomater 31: 1-16.

41. Altman GH, Diaz F, Jakuba C, Calabro T, Horan RL, et al. (2003) Silk-based biomaterials. Biomaterials 24(3): 401-416.

42.Zaoming W, Codina R, Fernández CE, Lockey RF (1996) Partial characterization of the silk allergens in mulberry silk extract. J Investig Allergol Clin Immunol 6(4): 237-241.

43. Chirila TV, Suzuki S, McKirdy NC (2016) Further development of silk sericin as a biomaterial: comparative investigation of the procedures for its isolation from Bombyx mori silk cocoons. Prog Biomater 5(2): 135145 .

44. Chirila T V, Suzuki S, Bray LJ, Barnett NL, Harkin DG (2013) Evaluation of silk sericin as a biomaterial: in vitro growth of human corneal limbal epithelial cells on bombyx mori sericin membranes. Prog Biomater 2(1): 14.

45. Liu B, Song Y, Jin L, Wang ZJ, Pu DY, et al. (2015) Silk structure and degradation. Colloids Surfaces B Biointerfaces 131: 122-128.

46. Bhardwaj N, Kundu SC (2012) Chondrogenic differentiation of rat MSCs on porous scaffolds of silk fibroin/chitosan blends. Biomaterials 33(10): 2848-2857.

47. Vishwanath V, Pramanik K, Biswas A (2016) Optimization and evaluation of silk fibroin-chitosan freeze-dried porous scaffolds for cartilage tissue engineering application. J Biomater Sci Polym Ed 27(7): 657-674.

48. Samal SK, Dash M, Chiellini F, Xiaoqin, Emo C, et al. (2014) Silk/chitosan biohybrid hydrogels and scaffolds via green technology. RSC Adv 4(96): 53547-53556.

49. Bhardwaj N, Nguyen QT, Chen AC, Kaplan DL, Sah RL, etal. (2011) Potential of 3-D tissue constructs engineered from bovine chondrocytes/silk fibroin-chitosan for in vitro cartilage tissue engineering. Biomaterials 32(25): 5773-5781.

50. Tamada Y (2005) New Process to form a silk fibroin porous 3-D structure. Biomacromolecules. 6(6): 3100-3106.

51. Foss C, Migliaresi C, Motta A (2013) The optimization of a scaffold for cartilage regeneration. Organogenesis 9(1): 19-21.

52.Zhang H, Liu X, Yang M, Zhu L (2015) Silk fibroin/sodium alginate composite nano-fibrous scaffold prepared through thermally induced phase-separation (TIPS) method for biomedical applications. Mater Sci Eng C 55: 8-13.

53. Wang Y, Kim UJ, Blasioli DJ, Kim HJ, Kaplan DL (2005) In vitro cartilage tissue engineering with 3D porous aqueous-derived silk scaffolds and mesenchymal stem cells. Biomaterials 26(34): 7082-7094.

54. Sawatjui N, Damrongrungruang T, Leeanansaksiri W, Jearanaikoon P, Hongeng S, et al. (2015) Silk fibroin/gelatin-chondroitin sulfatehyaluronic acid effectively enhances in vitro chondrogenesis of bone marrow mesenchymal stem cells. Mater Sci Eng C 52: 90-96.

55. Zheng L, Yang J, Fan H, Zhang X (2014) Material-induced chondrogenic differentiation of mesenchymal stem cells is material-dependent. Exp Ther Med 7(5): 1147-1150.

56. Uebersax L, Merkle HP, Meinel L (2008) Insulin-like growth factor I release silk fibroin scaffolds induce chondrogenic differentiation of human mesenchymal stem cells. J Control Release 127(1): 12-21. 
57. Ding X, Zhu M, Xu B (2014) Integrated trilayered silk fibroin scaffold for osteochondral differentiation of adipose-derived stem cells. ACS Appl Mater Interfaces 6(19): 16696-16705.

58. Wang Y, Blasioli D, Kim H, Kim H, Kaplan D (2006) Cartilage tissue engineering with silk scaffolds and human articular chondrocytes. Biomaterials 27(25): 4434-4442.

59. Bhattacharjee M, Chameettachal S, Pahwa S, Ray AR, Ghosh S (2014) Strategies for replicating anatomical cartilaginous tissue gradient in engineered intervertebral disc. ACS Appl Mater Interfaces 6(1): 183193.

60. Chen CH, Liu J, Chua CK, Chou SM, Shyu V, et al. (2014) Cartilage tissue engineering with silk fibroin scaffolds fabricated by indirect additive manufacturing technology. Materials (Basel) 7(3): 2104-2119.

61. Ni Y, Jiang Y, Wen J (2014) Construction of a functional silk-based biomaterial complex with immortalized chondrocytes in vivo. J Biomed Mater Res Part A 102(4): 1071-1078.

62. Zeng C, Yang Q Zhu M (2014) Silk fibroin porous scaffolds for nucleus pulposus tissue engineering. Mater Sci Eng C 37: 232-240.

63. Bhardwaj N, Kundu SC (2011) Silk fibroin protein and chitosan polyelectrolyte complex porous scaffolds for tissue engineering applications. Carbohydr Polym 85(2): 325-333.

64. Jaipaew J, Wangkulangkul P, Meesane J, Raungrut P, Puttawibul P (2016) Mimicked cartilage scaffolds of silk fibroin/hyaluronic acid with stem cells for osteoarthritis surgery: Morphological, mechanical, and physical clues. Mater Sci Eng C 64: 173-182.

65. Li Z, Liu P, Yang T (2016) Composite poly(L-lactic-acid)/silk fibroin scaffold prepared by electrospinning promotes chondrogenesis for cartilage tissue engineering. J Biomater Appl 30(10): 1552-1565.

66. Singh YP, Bhardwaj N, Mandal BB (2016) Potential of agarose/silk fibroin blended hydrogel for in vitro cartilage tissue engineering. ACS Appl Mater Interfaces 8(33): 21236-21249.

67. Sun K, Li R, Jiang W, Sun Y, Li H (2016) Comparison of three-dimensional printing and vacuum freeze-dried techniques for fabricating composite scaffolds. Biochem Biophys Res Commun 477(4): 1085-1091.

68. Tang Y, Cao C, Ma X, Chen C, Zhu H (2006) Study on the preparation of collagen-modified silk fibroin films and their properties. Biomed Mater 1(4): 242-246.

69. Zhou T, Wu J, Liu J, Luo Y, Wan Y (2015) Fabrication and characterization of layered chitosan/silk fibroin/nano-hydroxyapatite scaffolds with designed composition and mechanical properties. Biomed Mater 10(4): 045013.

70. Su D, Jiang L, Chen X, Dong J, Shao Z (2016) Enhancing the gelation and bioactivity of injectable silk fibroin hydrogel with laponite nanoplatelets. ACS Appl Mater Interfaces 8(15): 9619-9628.

71. Selvakumar R, Varkey A, Elakkiya V (2015) Impact of silk fibroin-based scaffold structures on human osteoblast MG63 cell attachment and proliferation. Int J Nanomedicine 10(Suppl 1): 43-51.

72. Zeng S, Liu L, Shi Y (2015) Characterization of silk fibroin/chitosan 3D porous scaffold and in vitro cytology. PLoS One 10(6): e0128658.

73. Shi P, Abbah SA, Saran K (2013) Silk fibroin-based complex particles with bioactive encrustation for bone morphogenetic protein 2 delivery. Biomacromolecules 14(12): 4465-4474.

74. Correia C, Bhumiratana S, Yan LP (2012) Development of silk-based scaffolds for tissue engineering of bone from human adipose-derived stem cells. Acta Biomater 8(7): 2483-2492.

75. Kim HJ, Kim UJ, Leisk GG, Bayan C, Georgakoudi I, et al. (2007) Bone regeneration on macroporous aqueous-derived silk 3-D scaffolds. Macromol Biosci 7(5): 643-655.

76. Meinel L, Fajardo R, Hofmann S (2005) Silk implants for the healing of critical size bone defects. Bone 37(5): 688-698.
77. Kim HJ, Kim UJ, Vunjak-Novakovic G, Min BH, Kaplan DL (2005) Influence of macroporous protein scaffolds on bone tissue engineering from bone marrow stem cells. Biomaterials 26(21): 4442-4452.

78. Gruchenberg K, Ignatius A, Friemert B (2015) In vivo performance of a novel silk fibroin scaffold for partial meniscal replacement in a sheep model. Knee Surgery, Sport Traumatol Arthrosc 23(8): 2218-2229.

79. Park YR, Ju HW, Lee JM (2016) Three-dimensional electrospun silkfibroin nanofiber for skin tissue engineering. Int J Biol Macromol 93: 1567-1574.

80. Rockwood DN, Preda RC, Yücel T, Wang X, Lovett ML, et al. (2011) Materials fabrication from Bombyx mori silk fibroin. Nat Protoc 6(10): 1612-1631.

81. Kim UJ, Park J, Joo Kim H, Wada M, Kaplan DL (2005) Three-dimensional aqueous-derived biomaterial scaffolds from silk fibroin. Biomaterials 26(15): 2775-2785.

82. Wang Y, Bella E, Lee CSD (2010) The synergistic effects of 3-D porous silk fibroin matrix scaffold properties and hydrodynamic environment in cartilage tissue regeneration. Biomaterials 31(17): 4672-4681.

83. Han K, Song JE, Tripathy N (2015) Effect of pore sizes of silk scaffolds for cartilage tissue engineering. Macromol Res 23(12): 1091-1097.

84. Moon BM, Kim DK, Park HJ (2014) Fabrication and characterization of three-dimensional silk fibroin scaffolds using a mixture of salt/sucrose. Macromol Res 22(12): 1268-1274.

85. Makaya K, Terada S, Ohgo K, Asakura T (2009) Comparative study of silk fibroin porous scaffolds derived from salt/water and sucrose/ hexafluoroisopropanol in cartilage formation. J Biosci Bioeng 108(1): 68-75.

86. Nazarov R, Jin HJ, Kaplan DL (2004) Porous 3-D Scaffolds from Regenerated Silk Fibroin. Biomacromolecules 5(3): 718-726.

87. Foss C, Merzari E, Migliaresi C, Motta A (2013) Silk fibroin/hyaluronic acid 3D matrices for cartilage tissue engineering. Biomacromolecules 14(1): 38-47.

88. Zhou F, Zhang X, Cai D (2017) Silk fibroin-chondroitin sulfate scaffold with immuno-inhibition property for articular cartilage repair. Acta Biomater 63: 64-75.

89. Mottaghitalab F, Farokhi M, Shokrgozar MA, Atyabi F, Hosseinkhani $\mathrm{H}$ (2015) Silk fibroin nanoparticle as a novel drug delivery system. J Control Release 206: 161-176.

90. Cao Y, Wang B (2009) Biodegradation of Silk Biomaterials. Int J Mol Sci 10(4): 1514-1524.

91. Wang Y, Rudym DD, Walsh A (2008) In vivo degradation of threedimensional silk fibroin scaffolds. Biomaterials 29(24-25): 3415-3428.

92. Kluge JA, Thurber A, Leisk GG, Kaplan DL, Luis Dorfmann A (2010) A model for the stretch-mediated enzymatic degradation of silk fibers. J Mech Behav Biomed Mater 3(7): 538-547.

93. Oseni AO, Crowley C, Boland MZ, Butler PE, Seifalian AM (2011) Tissue engineering for tissue and organ regeneration. In: Eberli D (ed.), Tissue Engineering for Tissue and Organ Regeneration. In Tech 2011: 233-257.

94. Heinegård D, Saxne T (2011) The role of the cartilage matrix in osteoarthritis. Nat Rev Rheumatol 7(1): 50-56.

95. Kobrina Y, Rieppo L, Saarakkala S (2013) Cluster analysis of infrared spectra can differentiate intact and repaired articular cartilage. Osteoarthr Cartil 21(3): 462-469.

96. Saha S, Kundu B, Kirkham J, Wood D, Kundu SC, et al. (2013) Osteochondral tissue engineering in vivo: A comparative study using layered silk fibroin scaffolds from mulberry and nonmulberry silkworms. Matsusaki M (ed.), PLoS One. 8(11): e80004.

97. Fragonas E, Valente M, Pozzi-Mucelli M (2000) Articular cartilage repair in rabbits by using suspensions of allogenic chondrocytes in alginate. Biomaterials 21(8): 795-801. 
98. Hunziker EB (2001) Growth-factor-induced healing of partial-thickness defects in adult articular cartilage. Osteoarthr Cartil 9(1): 22-32.

99. Lahner M, Kalwa L, Olbring R, Mohr C, Göpfert L, et al. (2015) Biomimetic structured surfaces increase primary adhesion capacity of cartilage implants. Technol Heal Care 23(2): 205-213.

100. Aydin HM (2011) A three-layered osteochondral plug: Structural, mechanical, and in vitro biocompatibility analysis. Adv Eng Mater 13(12): B511-B517.

101. Nooeaid P, Salih V, Beier JP, Boccaccini AR (2012) Osteochondral tissue engineering: scaffolds, stem cells and applications. J Cell Mol Med 16(10): 2247-2270.

102. Li JJ, Kim K, Roohani-Esfahani SI, Guo J, Kaplan DL, et al. (2015) A biphasic scaffold based on silk and bioactive ceramic with stratified properties for osteochondral tissue regeneration. J Mater Chem B 3(26): 5361-5376.

103. Makris E , Hu JC, Athanasiou K (2013) Hypoxia-induced collagen crosslinking as a mechanism for enhancing mechanical properties of engineered articular cartilage. Osteoarthritis Cartilage 21(4): 634641.

104. Nava MM, Draghi L, Giordano C, Pietrabissa R (2016) The effect of scaffold pore size in cartilage tissue engineering. J Appl Biomater Funct Mater 14(3): e223-229.

105. Di Luca A, Ostrowska B, Lorenzo-Moldero I (2016) Gradients in pore size enhance the osteogenic differentiation of human mesenchymal stromal cells in three-dimensional scaffolds. Sci Rep, doi:10.1038/ srep22898.

106. Xiao X, Wang W, Liu D (2015) The promotion of angiogenesis induced by three-dimensional porous beta-tricalcium phosphate scaffold with different interconnection sizes via activation of PI3K/Akt pathways. Sci Rep 5: 9409.

107. Xiao H, Huang W, Xiong K (2019) Osteochondral repair using scaffolds with gradient pore sizes constructed with silk fibroin, chitosan, and nano-hydroxyapatite. Int J Nanomedicine 14: 2011-2027.

108. Ruan S, Yan L, Deng J, Huang W, Jiang D (2017) Preparation of a biphase composite scaffold and its application in tissue engineering for femora osteochondral defects in rabbits. Int Orthop 41(9): 1899-1908.

109. Kirkpatrick CJ (2015) Modelling the regenerative niche: a major challenge in biomaterials research. Regen Biomater 2(4): 267-272.
110. Ribeiro VP, Pina S, Costa JB (2019) Enzymatically cross-linked silk fibroin-based hierarchical scaffolds for osteochondral regeneration. ACS Appl Mater Interfaces 11(4): 3781-3799.

111. Ghezzi CE, Marelli B, Donelli I, Alessandrino A, Freddi G, et al. (2015) Multilayered dense collagen-silk fibroin hybrid: a platform for mesenchymal stem cell differentiation towards chondrogenic and osteogenic lineages. J Tissue Eng Regen Med 4(7): 2046-2059.

112. Chen K, Ng KS, Ravi S, Goh JCH, Toh SL (2016) In vitro generation of whole osteochondral constructs using rabbit bone marrow stromal cells, employing a two-chambered co-culture well design. J Tissue Eng Regen Med 10(4): 294-304.

113. Liu J, Fang Q, Yu X, Wan Y, Xiao B (2018) Chitosan-based nanofibrous membrane unit with gradient compositional and structural features for mimicking calcified layer in osteochondral matrix. Int J Mol Sci 19(8): 2330

114. Yan LP, Silva-Correia J, Oliveira MB (2014) Bilayered silk/silk-nano $\mathrm{CaP}$ scaffolds for osteochondral tissue engineering: In vitro and in vivo assessment of biological performance. Acta Biomater 12(1): 227-241.

115. Çakmak S, Çakmak AS, Kaplan DL, Gümüşderelioğlu M (2016) A silk fibroin and peptide amphiphile-based co-culture model for osteochondral tissue engineering. Macromol Biosci 16(8): 1212-1226.

116. Li JJ, Kaplan DL, Zreiqat H (2014) Scaffold-based regeneration of skeletal tissues to meet clinical challenges. J Mater Chem B 2(42): 7272-7306.

117. Yong-woo L (1999) Silk reeling and testing manual. In: Food \& Agriculture Org, Food and Agriculture Organization of the United Nations, Rome, pp. 3-14.

118. Augst A, Marolt D, Freed LE (2008) Effects of chondrogenic and osteogenic regulatory factors on composite constructs grown using human mesenchymal stem cells, silk scaffolds and bioreactors. J R Soc Interface 5(25): 929-939.

119. Chen K, Teh TKH, Ravi S, Toh SL, Goh JCH (2012) Osteochondral interface generation by rabbit bone marrow stromal cells and osteoblasts coculture. Tissue Eng Part A 18(17-18): 1902-1911.

120. Chen K, Shi P, Teh TKH, Toh SL, Goh JC (2013) In vitro generation of a multilayered osteochondral construct with an osteochondral interface using rabbit bone marrow stromal cells and a silk peptide-based scaffold. J Tissue Eng Regen Med 10(4): 284-293. 